Original article

\title{
Influence of cotyledon removal on early seedling growth in Quercus robur $\mathbf{L}$.
}

\author{
Francisco García-Cebrián, Jordán Esteso-Martínez and Eustaquio Gil-Pelegrín* \\ Unidad de Recursos Forestales, Servicio de Investigación Agroalimentaria, Gobierno de Aragón, Apdo, 727, 50.080 Zaragoza, Spain
}

(Received 2 July 2001; accepted 7 February 2002)

\begin{abstract}
The process of resource transfer from seed to growing plant, in terms of dry matter and nitrogen, was studied in Quercus robur L. seedlings. In a factorial experiment, seedlings were subjected to cotyledon excision and shading just after shoot emergence. In another experiment, we removed the cotyledons at emergence and 7, 14 and 21 days later. The transfer of resources from cotyledons to growing plant seemed to be almost complete at a very early stage. Cotyledon excision just after shoot emergence resulted in a significant reduction in seedling growth. Shading had a minor effect during this period. However, the influence of cotyledons on seedling growth declines soon. Their artificial suppression had no significant effect when it was performed later than two weeks after shoot emergence. The consequences of this fact on the relationship between dispersion by jays and seedling growth are discussed.
\end{abstract}

Quercus robur L. / reserve effect / cotyledon / nitrogen transfer

Résumé - Influence de l'excision des cotylédons sur la croissance initiale des semis de Quercus robur L. On a étudié le mécanisme de transfert des réserves de glands de Quercus robur L. vers le semis, évalué par le poids sec et la teneur en azote. Dans une expérimentation factorielle, après la germination, les cotylédons ont été enlevés et les semis placés sous ombrage. Dans une deuxième expérimentation, les cotylédons ont été supprimés à différentes périodes : à la germination, 7, 14 et 21 jours après. Le transfert des réserves des cotylédons vers le semis semble être terminé très tôt. L'excision des cotylédons juste après la germination réduit significativement la croissance initiale des semis ; par contre, l'effet de l'ombrage durant cette période est plus faible. Néanmoins, l'influence des cotylédons sur la croissance des semis diminue très tôt. Sa suppression artificielle n'a pas d'effet significatif au-delà de deux semaines après la germination. Les conséquences de ce fait sur la relation entre les geais, principaux disperseurs des glands, et les chênes sont discutées.

Quercus robur L. / effet de réserve / cotylédon / transfert d'azote

\section{INTRODUCTION}

Oaks can be considered as typical of large seeded tree species in the northern hemisphere [14]. This reproductive strategy of higher plants, which implies a high effort in the construction of each single seed [9], has received different functional interpretations. On one hand, it has been suggested that large seeds could be more attractive to dispersal agents, resulting in a wider dispersion [1, 6, 24, 28].

On the other hand, it is widely accepted that big seeds can offer a large amount of metabolic reserves to the growing seedlings [31]. This may improve the early development of the growing plant [16] and increase its chances of survival. Such amounts of metabolizable compounds may allow the development of vigorous root systems able to explore large volumes of soil in nutrient poor sites $[2,7,10,25,30]$ or to reach deep soil horizons with larger moisture availability [3, 4, 15, 22].
Seed reserves would also allow the seedling to overcome temporal deficits in carbohydrate synthesis under low light conditions $[13,17,29]$. This positive effect of seed size on seedling growth affects not only final seedling size, but also its growth rate as shown in Merouani et al. [20]. These authors confirmed that seedlings of Quercus suber originating from the largest seeds had also the fastest growth rate.

The main objective of this paper was to deepen the knowledge of the role of large seeds in early seedling growth in Quercus. We wanted to define the term at which the plant does no longer depend on seed resources, as well as the importance of these resources under low light conditions as a stressing factor. With this aim, we first described the kinetic of resources transfer in terms of bulk biomass and nitrogen from the cotyledons to the seedling. Secondly, we analyzed the extent of the functional dependence between seedling growth and seed reserves by artificial suppression of cotyledon and by shading at different growth stages. 
Table I. Number of replications in each experiment, stage of growth and experimental conditions.

\begin{tabular}{|c|c|c|c|c|c|c|}
\hline \multicolumn{5}{|c|}{ Factorial experiment } & \multirow{2}{*}{\multicolumn{2}{|c|}{$\begin{array}{l}\text { Harvest at } \\
\text { different stages } \\
\text { of growth }\end{array}$}} \\
\hline & \multicolumn{2}{|c|}{ Full light } & \multicolumn{2}{|c|}{ Shade } & & \\
\hline Stage of growth & Control & Cotyledon removal & Control & Cotyledon removal & Control & Cotyledon removal \\
\hline Emergence & 40 & - & - & - & 40 & - \\
\hline 7 days & - & - & - & - & 15 & - \\
\hline 14 days & 31 & 22 & 28 & 28 & 31 & - \\
\hline 21 days & - & - & - & - & 14 & - \\
\hline 28 days & 36 & 23 & 32 & 10 & 36 & 23 \\
\hline 35 days & - & - & - & - & 18 & 15 \\
\hline 42 days & - & - & - & - & 16 & 16 \\
\hline 49 days & - & - & - & - & 15 & 17 \\
\hline
\end{tabular}

\section{MATERIALS AND METHODS}

Acorns were collected from a selected pure stand of Quercus robur at an elevation of 230 meters a.s.l. in Caldas de Reis (Pontevedra) in north western Spain during Autumn 1995. Procedures for acorn selection and storage followed the common recommendations for recalcitrant seeds $[8,12,19]$.

A total number of 546 seeds were sown on May 1996 and 376 seedlings were obtained. The fresh weight of each single acorn was recorded up to the first $0.1 \mathrm{~g}$ just prior to sowing. The ratio between seed fresh weight - pericarp included - and embryo dry weight - pericarp excluded - was established by linear regression in 60 acorns representing all the size variation found in the sample. The mean fresh weight of the seeds was $4.8 \mathrm{~g}(\mathrm{SD}=1.5)$.

Cylindrical pots, $300 \mathrm{~mm}$ in length and $70 \mathrm{~mm}$ of inner diameter, were used in order to adjust the container shape to the morphology of the root system of oak seedlings. Containers were filled with nutrient free sand. Nutrient supply was ensured by using a slow-liberation fertiliser as described by Naidu and DeLucia [23]. Plants were watered three times per week.

The experiments were performed in a greenhouse equipped with partial climatic control. Temperature and air relative humidity were recorded with a thermohygrograph (JRI MINIDISQUE 165-00, Jules Richard Instrument, Argenteuil, France). Mean air temperature was 21.8 (s.d. 3) and mean relative humidity was 85.2 (s.d. 8.6) through the experiment. A white shade screen was extended on the exterior of the greenhouse to tone down light intensity. The average maximum light level measured in the interior of the greenhouse was $760 \mu \mathrm{mol} \mathrm{m}^{-2} \mathrm{~s}^{-1}$. The measurements were carried out at midday with a PAR-sensor (ELE-International System, Hertfordshire, UK) during five cloudless days. The heliograph of a meteorological station close to the greenhouse pointed out that only $4.6 \%$ of the days were cloudy during the summer of 1996 , which made the light regime to be very regular through the plant growth period.

One of the aims of the present study was to analyse the evolution of early plant growth with respect to the consumption of seed reserves. Thus, the kinetic of changes in dry weight and in nitrogen content of both the cotyledons and the growing plant, was established prior to the analysis of the effect of cotyledon removal. To achieve this, a schedule of destructive harvests through seedling development was defined [7]. The harvesting schedule started just after full epicotyl development, when the shoot had reached a length of 5-7 cm and the leaves were not expanded yet (hereafter "shoot emergence"). The start time for harvests was defined for each single plant, depending on the date of emergence.
Another objective of this study was to analyse the combined effect of cotyledon removal and shading. The cotyledons of half of the seedlings were removed at emergence. Removed cotyledons were labelled and dried at $80^{\circ} \mathrm{C}$ during 48 hours. After this, the whole sample (with and without cotyledons) was divided and set into two different light conditions. Half of the sample was grown under full light conditions and the other half under a black screen which intercepted $90 \%$ of the incoming light. Four treatments resulted, namely full light/no excision (FL/NE), full light/excision (FL/E), shade/no excision $(\mathrm{S} / \mathrm{NE})$ and shade/excision $(\mathrm{S} / \mathrm{E})$. Plants from each treatment were also divided into three subsamples that were harvested at shoot emergence, 14 and 28 days after.

Finally, the effect of cotyledon removal on seedling growth was tested at different stages of plant development. Cotyledon excision was made at shoot emergence in one set of plants and 7,14 and 21 days after shoot emergence in three other sets of seedlings. Additional destructive harvests were also made simultaneously to record the dry weight of the plants at the time of excision. Seedlings were harvested 21 days after cotyledon removal. As a control, sets of unmanipulated plants were harvested in equal times.

In all cases, after harvesting, the whole plant was removed from the containers and the roots and shoots were washed with water until sand particles were completely eliminated. Clean plants were separated into cotyledons, pericarp, root, stem and leaves. These organs and the removed cotyledons were dried at $80^{\circ} \mathrm{C}$ for $48 \mathrm{~h}$ and weighted. Total nitrogen content was determined as an additional measure for each single sample by using the Kjeldahl method.

The number of individual seedlings used during each experiment and treatment are shown in table $I$. The effect of the experimental treatments and the possible interaction between factors were analysed by a two-way analysis of variance for each treatment combination and development stage with SAS Proc GLM (SAS Institute Inc., 1988) [26]. The effect of cotyledon removal on the average dry weight of plants at different developmental stages in experiment two was tested by a t-test.

\section{RESULTS}

Figure 1 shows the weekly time-course of dry matter and nitrogen content of cotyledons and growing seedlings under optimal irradiance and nutritional conditions. Sigmoidal models could be fitted to the data as described by Brookes et al. [7]. Both cotyledon dry matter and $\mathrm{N}$ content decreased down to an asymptotic threshold that was reached 3 and 4 weeks after shoot emergence respectively. A fraction of the cotyledon 

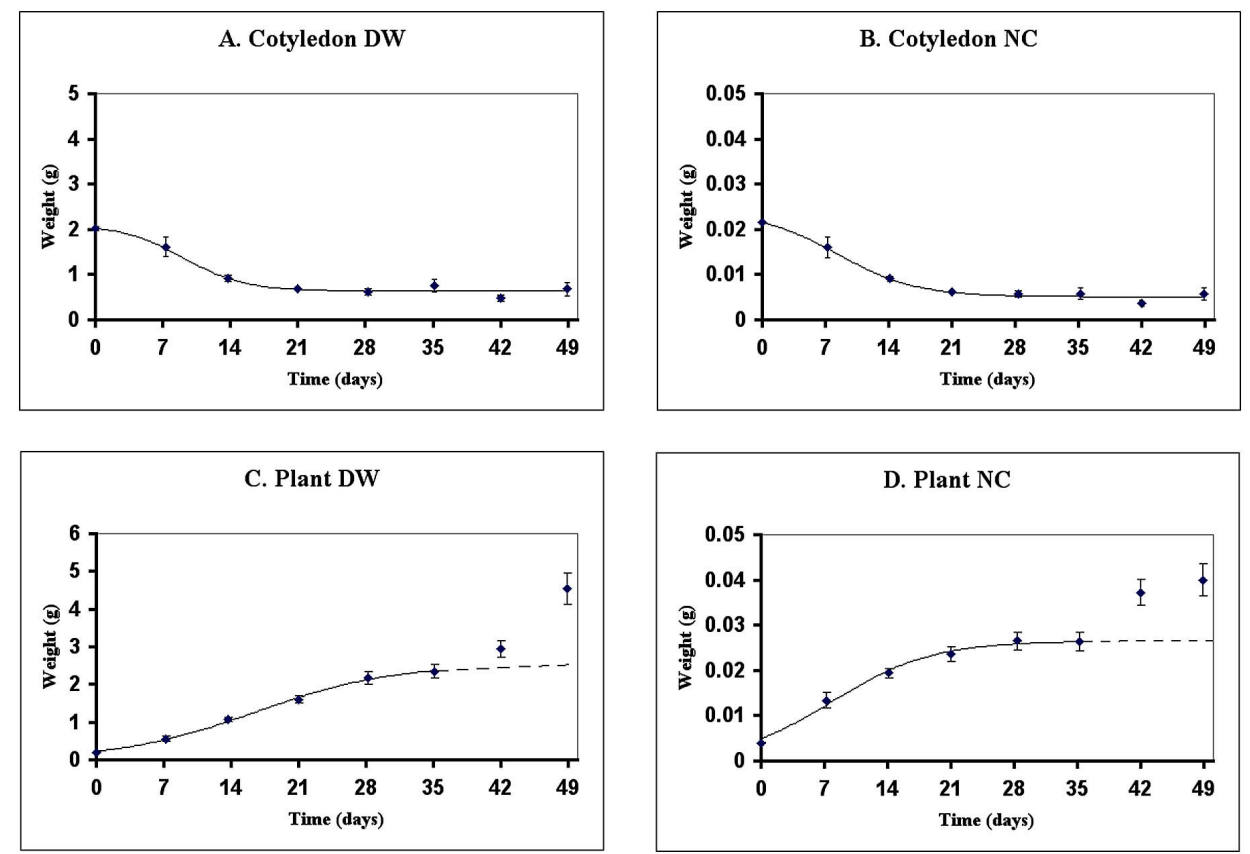

Figure 1. Time course of dry weight and total nitrogen content in cotyledons and seedlings of $Q$. robur, mean \pm S.E. A sigmoid model was fit to the data. The model has been graphically extended in $\mathrm{C}$ and $\mathrm{D}$ for a better comprehension (dotted part of line).

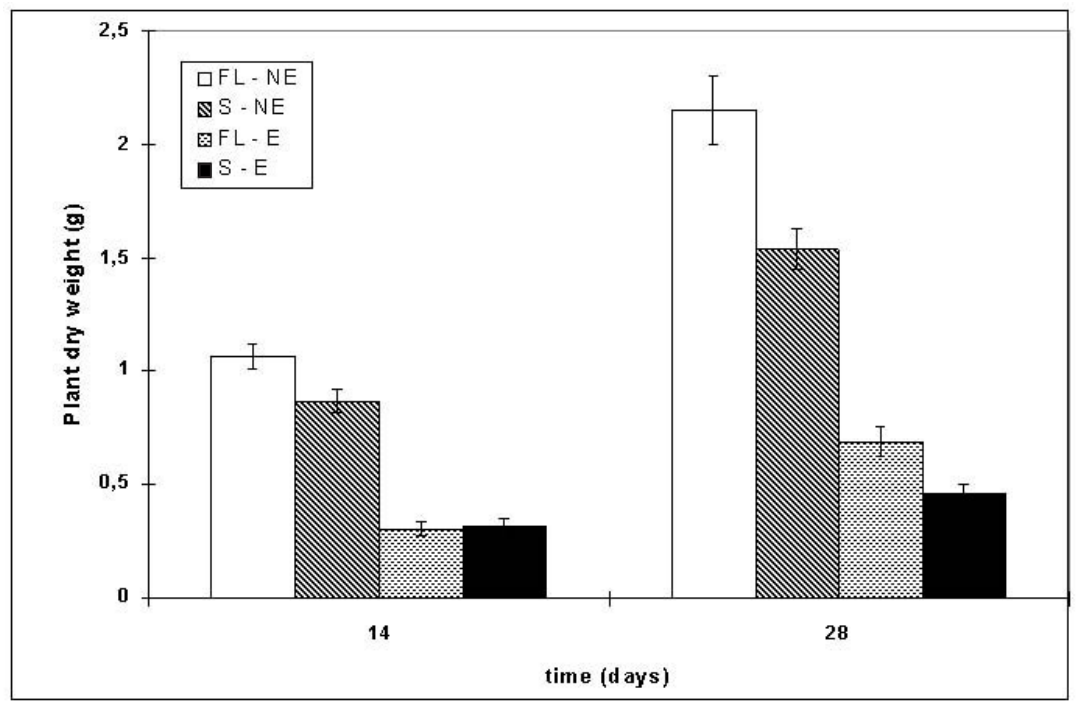

Figure 2. Dry weight of $Q$. robur seedlings 2 or 4 weeks after emergence, as a function of irradiance (FL: full light; S: shade) and of cotyledon severing at shoot emergence (NE: no excision; E: excision). Means \pm S.E.

biomass (31.2\%) and nitrogen content (27.2\%) was not therefore transferred to the growing plant. Similarly, seedling dry matter and nitrogen content increased and reached a plateau until the beginning of the second growth flush that began 35 days after emergence.

Cotyledon removal at emergence and shade had significant effects on seedling biomass reached 2 or 4 weeks after emergence (figure 2 and table II). Shade induced a significant reduction of growth that was already visible 2 weeks after emergence, and increased during the third one (approx. 1.3 times more biomass in the light). The impact of cotyledon severing was nevertheless much larger, resulting in a biomass reduction by approximately a factor 3 as compared to the respective controls. Interestingly, cotyledon removal reduced growth to a larger extent in the light than under shade.

The time course of the impact of cotyledon severing after increasing time lags following emergence are shown in figure 3. The impact of severing was significant at emergence and one week later, but had no effect when practised 2 or 3 weeks after emergence. 


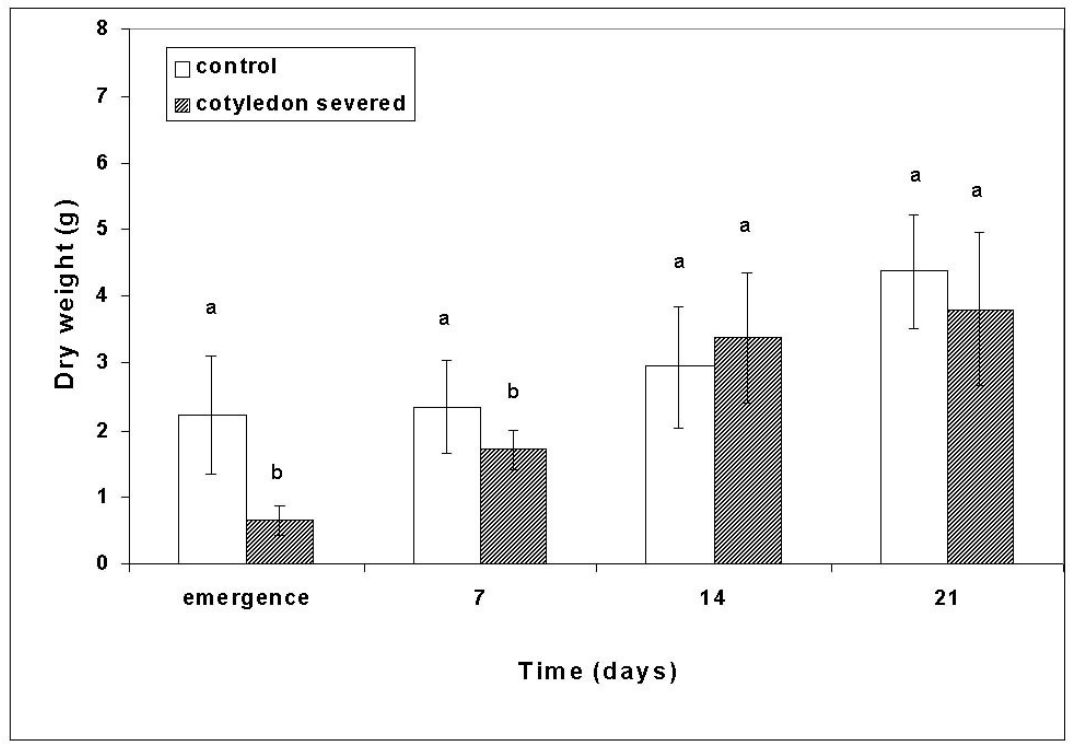

Figure 3. Seedling dry weight measured three weeks after cotyledon severing as a function of the delay between emergence and severing $(0,1,2,3$ weeks after emergence). Means \pm S.E. Different letter indicates significant differences $(P>0.05)$ between treatments for each severing time.

Table II. F statistics and significance levels for MANOVA. See text for details.

\begin{tabular}{clrrr}
\hline $\begin{array}{c}\text { Growth stage } \\
\text { (days) }\end{array}$ & \multicolumn{1}{c}{$\begin{array}{c}\text { Source of } \\
\text { variation }\end{array}$} & df & F value & Sig. Level \\
\hline \multirow{4}{*}{14} & Light & 1 & 4.36 & 0.0392 \\
& Cotyledon severing & 1 & 181.287 & 0 \\
& Light $\times$ Severing & 1 & 4.455 & 0.0372 \\
& Error & 106 & & \\
\hline \multirow{2}{*}{28} & Light & 1 & 5.69 & 0.019 \\
& Cotyledon severing & 1 & 95.32 & 0.0001 \\
& Light $\times$ Severing & 1 & 1.95 & 0.1658 \\
& Error & 99 & & \\
\hline & & & &
\end{tabular}

\section{DISCUSSION}

The results of this study should help to understand the role of seed reserves on early seedling growth in Quercus species. The availability of an extra amount of metabolic resources stored in the large cotyledons is considered to increase the chances for the young plant to establish successfully in the forest understory. Lord et al. [18] concluded that the abundance of large seeds in tropical floras could be explained by the higher metabolic costs for converting seed reserves into seedlings under elevated temperatures. The sharp reduction on consecutive plant growth observed when cotyledons were removed at emergence, both under high light conditions as under deep shading, corroborates this last idea. Reduction on seedling growth as a consequence of early cotyledon extirpation has been also demonstrated by Frost and Rydin [11], Milberg and Lamont [21] and Bonfil [5].

However the "reserve effect", as defined by Saverimuttu and Westoby [27], declines rapidly during seedling development. The early decline of resource transfer rate from seed results in the reduction of the effect of extirpation as the seed- ling grows. In fact, according to our results, the extent of the transfer reaches $80 \%$ of the biomass and $73 \%$ of the nitrogen content respectively only 14 days after shoot emergence.

Some authors have reported that cotyledon extirpation had no effect on growth in oaks $[1,15,28]$. Our results support this finding but only when excision is practised 14 or 21 days after shoot emergence. Although we are unable to compare exactly the time of removal between these studies and ours, we suspect that extirpation must have been done later than the critical moment detected by us (around fourteen days after s.e.).

The role of seed predators is potentially large during the early seedling life. As pointed out by Sonesson [28], Garrulus glandarius L. has a key role in oak stands regeneration, searching, transporting and hoarding acorns during autumn. However, when seedlings emerge in spring, jays remove the edible cotyledons and feed their fledglings with them. In this way, jays may reduce the viability of oak seedlings if cotyledons were removed at a very early moment (i.e., before 14th day since emergence). Afterwards, predation would have no or only a little effect if resource transfer had almost concluded.

Acknowledgements: We are most grateful to Dr. Kerstin Sonesson and two anonymous reviewers for the useful comments about a preliminary draft of this paper. This study has been supported by the "Comisión Interministerial de Ciencia y Tecnología" project AGF960399, Spain.

\section{REFERENCES}

[1] Andersson C., Frost I., Growth of Quercus robur seedlings after experimental grazing and cotyledon removal, Acta Bot. Neerl. 45 (1996) 85-94.

[2] Allsopp N., Stock W.D., Relationships between seed reserves, seedling growth and mycorrhizal responses in 14 related shrubs (Rosidae) from a low-nutrient environment, Funct. Ecol. 9 (1995) 248-254. 
[3] Bacilieri R., Bouchet M.A., Bran D., Grandjanny M., Maistre M., Perret P., Romane F., Germination and regeneration mechanisms in Mediterranean degenerate forests, J. Veget. Sci. 4 (1993) 241-246.

[4] Baker H.G., Seed weight in relation to environmental conditions in California, Ecology 53 (1972) 997-1010.

[5] Bonfil C., The effects of seed size, cotyledon reserves and herbivory on seedling survival and growth in Quercus rugosa and Q. laurina (Fagaceae), Am. J. Bot. 85 (1998) 79-87.

[6] Bossema I., Jays and oaks: an eco-ethological study of a symbiosis, Behaviour 70 (1979) 1-117.

[7] Brookes P.C., Wigston D.L., Bourne W.F., The dependence of Quercus robur and Quercus petraea seedlings on cotyledon potassium, magnesium, calcium and phosphorus during the first year of growth, Forestry 53 (1980) 168-177.

[8] Catalán-Bachiller G., Semillas de árboles y arbustos forestales, Colección Técnica ICONA-MAPA, 1991.

[9] Farmer R.E. Jr., Seed ecophysiology of temperate and boreal zone forest trees, St. Lucie Press, Delray Beach, Florida, 1997.

[10] Foster S.A., On the adaptive value of large seeds for tropical moist forest trees: a review and synthesis, Bot. Rev. 52 (1986) 260-299.

[11] Frost I., Rydin H., Effects of competition, grazing and cotyledon nutrient supply on growth of Quercus robur seedlings, Oikos 79 (1997) 53-58.

[12] Gribko L.S., Jones W.E., Test of the float method of assessing northern Red Oak acorn condition, Tree Plant. Notes 46 (1995) 143-147.

[13] Grime J.P., Jeffrey D.W., Seedling establishment in vertical gradients of sunlight, J. Ecology 53 (1965) 621-642.

[14] Harper J.L., Lovell P.H., Moore K.G., The shapes and sizes of seeds, An. Rev. Ecol. System. 1 (1970) 327-356.

[15] Jarvis P.G., The effects of acorn size and provenance on the growth of seedlings of sessile oak, Q. J. For. 57 (1963) 11-19.

[16] Jurado E., Westoby M., Seedling growth in relation to seed size among species of arid Australia, J. Ecol. 80 (1992) 407-416.

[17] Leishman M.R., Westoby M., The role of large seed size in shaded conditions: experimental evidence, Funct. Ecol. 8 (1994) 205-214.

[18] Lord J., Egan J., Clifford T., Jurado E., Leishman M., Williams D., Westoby M., Larger seeds in tropical floras: consistent patterns independent of growth form and dispersal mode, J. Biogeogr. 24 (1997) 205-211.

[19] Merouani H., Branco C., Almeida M.H., Pereira J.S., Comportement physiologique des glands de chêne liège (Quercus suber L.) durant leur conservation et variabilité inter-individus producteurs, Ann. For. Sci. 58 (2001) 143-153.

[20] Merouani H., Branco C., Almeida M.H., Pereira J.S., Effects of acorn storage duration and parental tree on emergence and physiological status of Cork oak (Quercus suber L.) seedlings, Ann. For. Sci. 58 (2001) 543-554.

[21] Milberg P., Lamont B.B., Seed/cotyledon size and nutrient content play a major role in early performance of species on nutrient-poor soils, New Phytol. 137 (1997) 665-672.

[22] Mosandl R., Kleinert A., Development of oaks (Quercus petraea (Matt.) Liebl.) emerged from bird-dispersed seeds under oldgrowth pine (Pinus silvestris L.) stands, For. Ecol. Manage. 106 (1998) 35-44.

[23] Naidu S.L., DeLucia E.H., Growth, allocation and water relations of shade-grown Quercus rubra L. samplings exposed to a lateseason canopy gap, Ann. Bot. 80 (1997) 335-344.

[24] Oakwood M., Jurado E., Leishman M., Westoby M., Geographic ranges of plant species in relation to dispersal morphology, growth form and diaspore weight, J. Biogeogr. 20 (1993) 563-572.

[25] Ovington J.D., MacRae C., The growth of seedlings of Quercus petraea, J. Ecol. 48 (1960) 549-555.

[26] SAS / STAT TM, Guide for personal computers, Version 6 ed., Carg. NC, SAS Institute Inc., 1998.

[27] Saverimuttu T., Westoby M., Seedling longevity under deep shade in relation to seed size, J. Ecol. 84 (1996) 681-689.

[28] Sonesson L.K., Growth and survival after cotyledon removal in Quercus robur seedlings, grown in different natural soil types, Oikos 69 (1994) 65-70.

[29] Tripathi R.S., Khan M.L., Effects of seed weight and microsite characteristics on germination and seedling fitness in two species of Quercus in a subtropical wet hill forest, Oikos 57 (1990) 289-296.

[30] Venable D.L., Size-number trade-offs and the variation of seed size with plant resource status, Am. Nat. 140 (1992) 287-304.

[31] Westoby M., Jurado E., Leishman M., Comparative evolutionary ecology of seed size, Tree 7 (1992) 368-372. 